\title{
$\beta$-Amyloid Modulation of Synaptic Transmission and Plasticity
}

\author{
Deepa V. Venkitaramani, ${ }^{1}$ Jeannie Chin, ${ }^{2}$ William J. Netzer, ${ }^{3}$ Gunnar K. Gouras, ${ }^{4}$ Sylvain Lesne, ${ }^{5}$ Roberto Malinow, ${ }^{6}$ and \\ Paul J. Lombroso ${ }^{1}$ \\ ${ }^{1}$ Child Study Center, Yale University School of Medicine, New Haven, Connecticut 06520, ${ }^{2}$ Gladstone Institute of Neurological Disease, University of \\ California, San Francisco, San Francisco, California 94158, ${ }^{3}$ Laboratory of Molecular and Cellular Neuroscience, and Fisher Center for Research on \\ Alzheimer Disease, The Rockefeller University, New York, New York 10065, ${ }^{4}$ Department of Neurology and Neuroscience, Weill Medical College of Cornell \\ University, New York, New York 10021, ${ }^{5}$ Grossman Center for Memory Research and Care, University of Minnesota Medical School, Minneapolis, \\ Minnesota 55455, and ${ }^{6}$ Cold Spring Harbor Laboratory, Cold Spring Harbor, New York 11724
}

Key words: A $\beta$ peptide; Alzheimer's disease; Down syndrome; glutamate receptor; synaptic plasticity; Fyn; STEP; striatal-enriched tyrosine phosphatase

The sequencing of $\beta$ amyloid protein $(A \beta)$ in 1984 led to the formulation of the "amyloid hypothesis" of Alzheimer's disease (AD) (Glenner and Wong, 1984). The hypothesis proposed that accumulation of $\mathrm{A} \beta$ is responsible for $\mathrm{AD}$-related pathology, including $\mathrm{A} \beta$ deposits, neurofibrillary tangles, and eventual neuronal cell death (Tanzi and Bertram, 2005). Within a few years, four groups cloned the amyloid precursor protein (APP) gene from which A $\beta$ is processed (Goldgaber et al., 1987; Kang et al., 1987; Robakis et al., 1987; Tanzi et al., 1987). Linkage analysis mapped the gene to chromosome 21, and mutations in $A P P$ were found that led to the inappropriate processing of APP into the $A \beta_{1-42}$ peptide (Goate et al., 1991; Mullan et al., 1992) (for review, see Tanzi and Bertram, 2005). However, these mutations are responsible for only a small fraction of the early-onset familial AD, and the search began for other genes that might also influence the processing of $\mathrm{A} \beta$. Several novel mutations were identified in the presenilins (Levy-Lahad et al., 1995; Rogaev et al., 1995; Sherrington et al., 1995), and apolipoprotein E4 was identified as a major risk factor for the most frequent form of $\mathrm{AD}$ (Strittmatter et al., 1993; Mahley et al., 2006).

Two models have emerged to explain the etiology of AD. The first model, mentioned above, proposes that fibrillary $\mathrm{A} \beta$ deposits are responsible for the eventual neuronal degeneration (Selkoe, 1991; Hardy and Higgins, 1992). A second more recent model suggests that soluble $\mathrm{A} \beta$ oligomers disrupt glutamatergic synaptic function, which in turn leads to the characteristic cognitive deficits (Lambert et al., 1998; Hsia et al., 1999; Klein et al., 2001; Hardy and Selkoe, 2002; Klein, 2002; Kamenetz et al., 2003; Walsh and Selkoe, 2004).

One difficulty with the original amyloid hypothesis is the fact that the temporal patterns of amyloid deposits do not correlate

Received July 31, 2007; revised Sept. 11, 2007; accepted Sept. 16, 2007.

This work was supported by National Institutes of Health Grants MH52711, MH01527, NS33249, NS045677, NS041787, and AG022074.

Correspondence should be addressed to Paul J. Lombroso, Child Study Center, Yale University School of Medicine, 230 South Frontage Road, New Haven, CT 06520. E-mail: paul.lombroso@yale.edu.

DOI:10.1523/JNEUROSCI.3478-07.2007

Copyright $\odot 2007$ Society for Neuroscience $\quad$ 0270-6474/07/2711832-06\$15.00/0 well with the cognitive deficits in affected patients (Katzman et al., 1988). In fact, the best correlations with cognitive deficits are the loss of synaptic structure and function (Terry et al., 1991). Synaptic plasticity [e.g., long-term potentiation (LTP)] is impaired before $A \beta$ deposits are detected in mouse models of $A D$ (Hsia et al., 1999; Larson et al., 1999). In addition, soluble A $\beta$ oligomers selectively block LTP (Walsh et al., 2002) and acutely disrupt cognitive function after infusion into the CNS (Cleary et al., 2005; Lesne et al., 2006). They also bind with a punctate pattern to excitatory pyramidal neurons but not to GABAergic neurons (Lacor et al., 2004, 2007) and lead to synaptic loss (Hsieh et al., 2006; Shankar et al., 2007). Together, these results suggest that impairment in synaptic function is an early event in the pathogenesis of $\mathrm{AD}$. Uncovering the mechanisms whereby $\mathrm{A} \beta$ oligomers induce synaptic deficits is still at an early stage, and currently there is no consensus on the precise molecular pathways involved. A number of intracellular signaling pathways have been implicated in $\mathrm{A} \beta$-induced synaptic dysfunction, and different sources or assembly states of $A \beta$ oligomers may have different effects on synaptic function. Moreover, the relative involvements of intracellular and extracellular $\mathrm{A} \beta$ oligomers remain to be defined.

\section{Striatal-enriched tyrosine phosphatase and glutamate receptor trafficking}

The role of $A \beta$ in synaptic dysfunction was the subject of a minisymposium at the 37th Annual Meeting of the Society for Neuroscience. The first presentation by Deepa Venkitaramani discussed the role of striatal-enriched tyrosine phosphatase (STEP) in regulating glutamate receptor trafficking. STEP normally opposes the development of synaptic plasticity through its ability to dephosphorylate regulatory tyrosine residues on key signaling molecules (Lombroso et al., 1991, 1993) (Fig. 1). Thus, the dephosphorylation by STEP of extracellular signal-regulated kinase 1/2 (ERK1/2) and Fyn leads to their inactivation, whereas dephosphorylation of the NR2B subunit of the NMDA receptor at $\mathrm{Tyr}^{1472}$ results in endocytosis of the receptor complex (Nguyen et al., 2002; Paul et al., 2003; Snyder et al., 2005). A $\beta$ was recently shown to activate STEP, which in turn dephosphorylates NR2B 

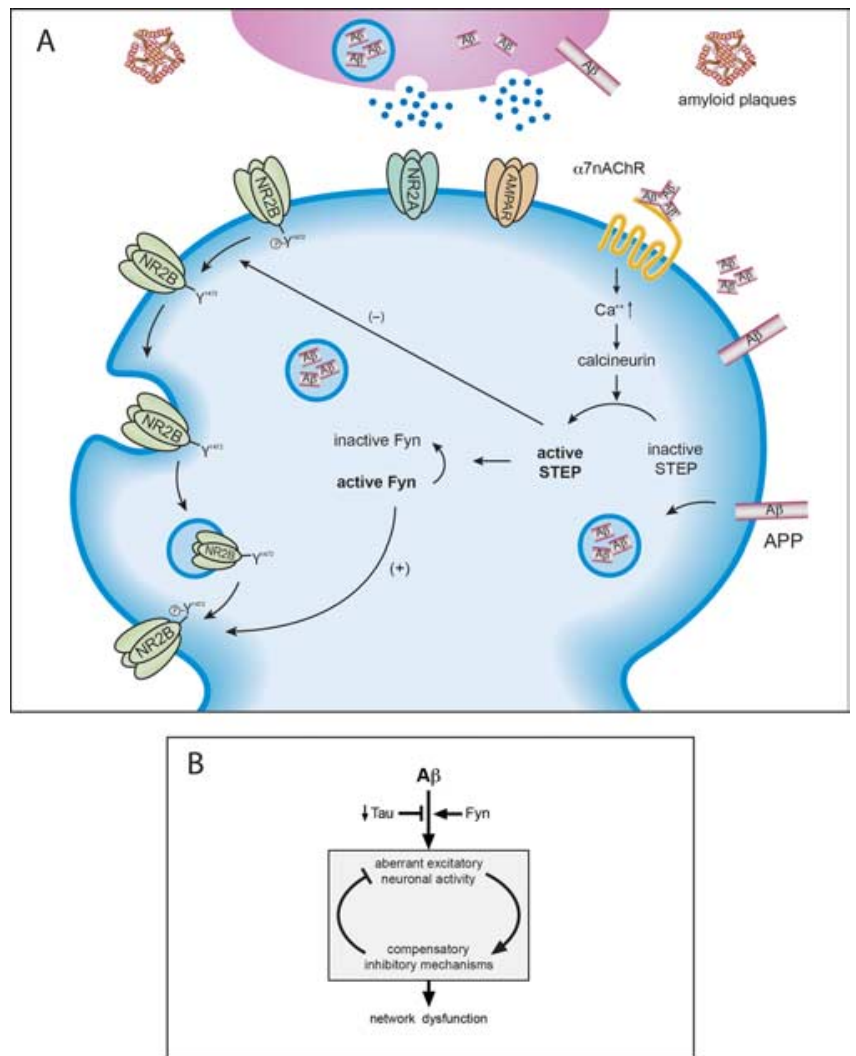

Figure 1. A, Activation of STEP leads to NMDA receptor endocytosis. A $\beta$ binding to the $\alpha 7$ nicotinic acetylcholine receptor results in $\mathrm{Ca}^{2+}$ influx, calcineurin activation, and the dephosphorylation and activation of STEP. A trimer is shown binding to the receptor, although it is not clear which of the higher molecular weight oligomers is involved. STEP in turn dephosphorylates a regulatory tyrosine $\left(\mathrm{Y}^{1472}\right)$ on the NR2B subunit of the NMDA receptor, as well as dephosphorylates and inactivates Fyn, the tyrosine kinase that phosphorylates NR2B-Y ${ }^{1472}$. STEP thus uses two distinct pathways to promote NMDA receptor internalization. $\boldsymbol{B}$ summarizes findings that suggest that a net increase in aberrant activity triggers compensatory inhibitory mechanisms to limit overexcitation but diminish the capacity for synaptic plasticity and lead to network dysfunction. This model proposes that Fyn kinase exacerbates, whereas tau reduction ameliorates, $A \beta$-induced aberrant neuronal activity. $\alpha 7 \mathrm{nAChR}, \alpha 7$-Nicotinic acetylcholine receptor; AMPAR, AMPA receptor.

(Snyder et al., 2005). Moreover, STEP also inactivates Fyn, a tyrosine kinase that phosphorylates NR2B at Tyr ${ }^{1472}$. Phosphorylation at that site promotes exocytosis of the NMDA receptor complex (Hallett et al., 2006). Thus, STEP decreases the surface expression of NMDA receptors through two mechanisms (Snyder et al., 2005; Braithwaite et al., 2006). These studies were done with synthetic or oligomeric $\mathrm{A} \beta$ secreted by cultured cells, and, currently, experiments are underway to determine whether purified higher-molecular-weight oligomers have varying synaptic effects (see below). A $\beta$ was also shown to lead to the endocytosis of AMPA receptors (Almeida et al., 2005; Hsieh et al., 2006).

These results have led to the hypothesis that reducing STEP levels may increase glutamate receptors at surface membrane. Data were presented from STEP knock-out (KO) mice in support of this hypothesis, because basal phosphorylation levels of ERK1/2 and their downstream substrates are upregulated in the KO mice. Moreover, these mice have increased surface expression of glutamate receptors (both AMPA and NMDA). The results raise the intriguing possibility that reducing STEP levels may help alleviate some of the cognitive deficits caused by the synaptic actions of $\mathrm{A} \beta$.

\section{$\beta$ Amyloid and Fyn in neuronal network dysfunction}

Jeannie Chin then discussed the role of Fyn kinase and related pathways in sensitizing neurons to $\mathrm{A} \beta$ (Fig. $1 B$ ). Transgenic mice expressing moderate levels of human APP/A $\beta$ (hAPP-J9) exhibit a relatively subtle $\mathrm{AD}$-like phenotype. In contrast, overexpression of Fyn and $\mathrm{A} \beta$ in FYN/hAPP-J9 double-transgenic mice results in severe neuronal and cognitive impairments similar to those otherwise seen only in hAPP mice with much higher levels of A $\beta$ production (hAPP-J20 mice) (Palop et al., 2003; Chin et al., 2004, 2005; Palop et al., 2005). In addition, ablation of Fyn prevents several aspects of $\mathrm{A} \beta$-induced neurotoxicity (Lambert et al., 1998; Chin et al., 2004). These findings indicate that A $\beta$ and Fyn may act synergistically in vivo.

Fyn increases NMDA receptor-mediated currents, modulates release of calcium from intracellular stores, and enhances synaptic transmission (Kojima et al., 1998; Lu et al., 1999; Cui et al., 2004; Salter and Kalia, 2004) and hence may cooperate with A $\beta$ to sensitize neurons to overexcitation. Consistent with this hypothesis, recent studies from Lennart Mucke's laboratory demonstrated that both hAPP-J20 single transgenic mice and FYN/ hAPP-J9 double transgenic mice exhibit spontaneous nonconvulsive seizure activity in cortical and hippocampal networks and increased seizure severity after inhibition of $\mathrm{GABA}_{\mathrm{A}}$ receptors (Palop et al., 2007). This increased seizure susceptibility is associated with prominent sprouting of inhibitory circuit elements and depletion of calcium- and activity-dependent proteins in the dentate gyrus (Palop et al., 2007). These cellular alterations may serve as compensatory inhibitory mechanisms against excitotoxicity (Vezzani et al., 1999; Palop et al., 2007). Notably, levels of active Fyn in the dentate gyrus are lower in hAPP-J20 mice than in controls. Moreover, levels of STEP, the phosphatase that inactivates Fyn, are strikingly increased, suggesting that suppression of Fyn activity may be a protective response in this brain region. Together, these studies suggest that $\mathrm{A} \beta$ and Fyn synergize to induce aberrant increases in neuronal activity, triggering inhibitory mechanisms that limit network overexcitation but that may also diminish the capacity for synaptic plasticity.

It is important to note that hAPP-J20 mice also have reduced levels of AMPA receptor subunits and LTP impairments in the dentate gyrus (Palop et al., 2007). Thus, aberrant increases in overall network activity coexist with impairments in glutamatergic transmission. The relationship between these two phenomena remains to be defined, but there are several possibilities that could help explain their coexistence. For example, depression of glutamatergic transmission could serve as a compensatory response or scaling mechanism triggered by overexcitation, or brain regions that control neuronal excitability on a global scale could be particularly susceptible to this $\mathrm{A} \beta$-induced depression.

\section{$\boldsymbol{\beta}$ Amyloid and Down syndrome}

William Netzer next discussed the role of $A \beta$ in Down syndrome (DS). DS is the most common, genetic form of mental retardation (Epstein, 1990) and is typically associated with AD pathology by the fourth decade (Schupf and Sergievsky, 2002). DS results from trisomy of chromosome 21, which involves triplication of $>100$ genes, including APP and other genes known to affect APP (Deutsch et al., 2003; Antonarakis et al., 2004). APP levels are elevated fourfold to fivefold compared with controls (Beyreuther et al., 1993). APP triplication predicts a 1.5-fold increase in APP levels and therefore does not explain the magnitude of this elevation. Additional factors may include triplication of the transcription factor ETS2, whereas other triplicated genes in DS, such as 
S100 $\beta$ and superoxide dismutase, have been implicated in amyloid deposition and metabolism, as has increased BACE1 ( $\beta$-site APPcleaving enzyme) maturation and activity (Griffin et al., 1998; Wolvetang et al., 2003; Lott et al., 2006).

Several mouse models of DS have been established. Of these, the Ts65Dn mouse is considered the gold standard because it displays many phenotypic aspects of human DS (Davisson et al., 1993). Ts65Dn is the result of a partial trisomy of mouse chromosome 16, containing all the genes within the human DS "critical region." The mice display pronounced behavioral and cognitive deficits and disruption of hippocampal LTP (Escorihuela et al., 1995; Holtzman et al., 1996; Siarey et al., 1997; Kleschevnikov et al., 2004).

The Ts65Dn mouse also develops a cholinergic pathology at or slightly before 6 months of age (Holtzman et al., 1991; Hunter et al., 2003). However, because the behavioral and electrophysiological deficits in these mice are present at 2-4 months, the group addressed the possibility that elevated $\mathrm{A} \beta$ levels contribute to the human DS phenotype at all ages, and these were detected in Ts65Dn brains compared with littermate controls. Behavioral deficits (Morris water maze) were consistent with previous reports (Escorihuela et al., 1995), and preliminary data suggest that some of these deficits can be rescued by lowering $A \beta$ levels.

\section{Intraneuronal $\boldsymbol{\beta}$ amyloid in synaptic dysfunction}

Gunnar Gouras then presented how intraneuronal accumulation of $\mathrm{A} \beta$ peptides contributes to functional alterations at synapses. Numerous laboratories have reported the intraneuronal accumulation of $\mathrm{A} \beta$ in transgenic mouse models of $\mathrm{AD}$ as well as human AD and DS (Gouras et al., 2005; LaFerla et al., 2007). Intraneuronal $\mathrm{A} \beta$ accumulation correlates with the onset of synaptic and behavioral abnormalities in transgenic models of $\mathrm{AD}$ (Oddo et al., 2003; Echeverria et al., 2004; Billings et al., 2005; Knobloch et al., 2007). Marked intraneuronal accumulation of A $\beta$ was associated with early ultrastructural pathology, especially within distal processes and synaptic compartments (Takahashi et al., 2004).

Cultured neurons derived from $\mathrm{AD}$ transgenic mice provide a cellular model to study the cellular mechanism(s) whereby intraneuronal A $\beta$ accumulation leads to synaptic abnormalities. Transgenic APP mutant compared with wild-type neurons develop progressive $\mathrm{AD}$-like alterations in presynaptic and postsynaptic proteins, including early reductions in postsynaptic density-95 and glutamate receptors at synapses. These synaptic alterations can be prevented by reduction of $\mathrm{A} \beta$ by treatment with $\gamma$-secretase inhibitor or A $\beta$ antibody (Almeida et al., 2005; Snyder et al., 2005; Tampellini et al., 2007). Evidence supports a dynamic relationship between the extracellular and intracellular pools of $\mathrm{A} \beta$ that remains poorly defined and may be critical in $\mathrm{A} \beta$-induced synaptic dysfunction (Glabe, 2001; Oddo et al., 2006).

\section{Role of $\beta$ amyloid ${ }^{\star} 56$ in memory impairment}

Sylvain Lesne next discussed the function of the soluble $56 \mathrm{kDa}$ amyloid- $\beta$ oligomer $\left(\mathrm{A} \beta^{\star} 56\right)$ in the aging brain of $\mathrm{Tg} 2576$ mice (Fig. $2 A$ ). Although the effects of synthetic soluble $A \beta$ oligomers and $\mathrm{A} \beta$ oligomers secreted by cultured cells include impairment of neuronal survival (Lambert et al., 1998; Kayed et al., 2003), inhibition of LTP (Walsh et al., 2002), disruption of behavior (Cleary et al., 2005), and endocytosis of NMDA receptors (Snyder et al., 2005), those of endogenous soluble $A \beta$ assemblies have only recently been studied (Lesne et al., 2006). Data were pre-

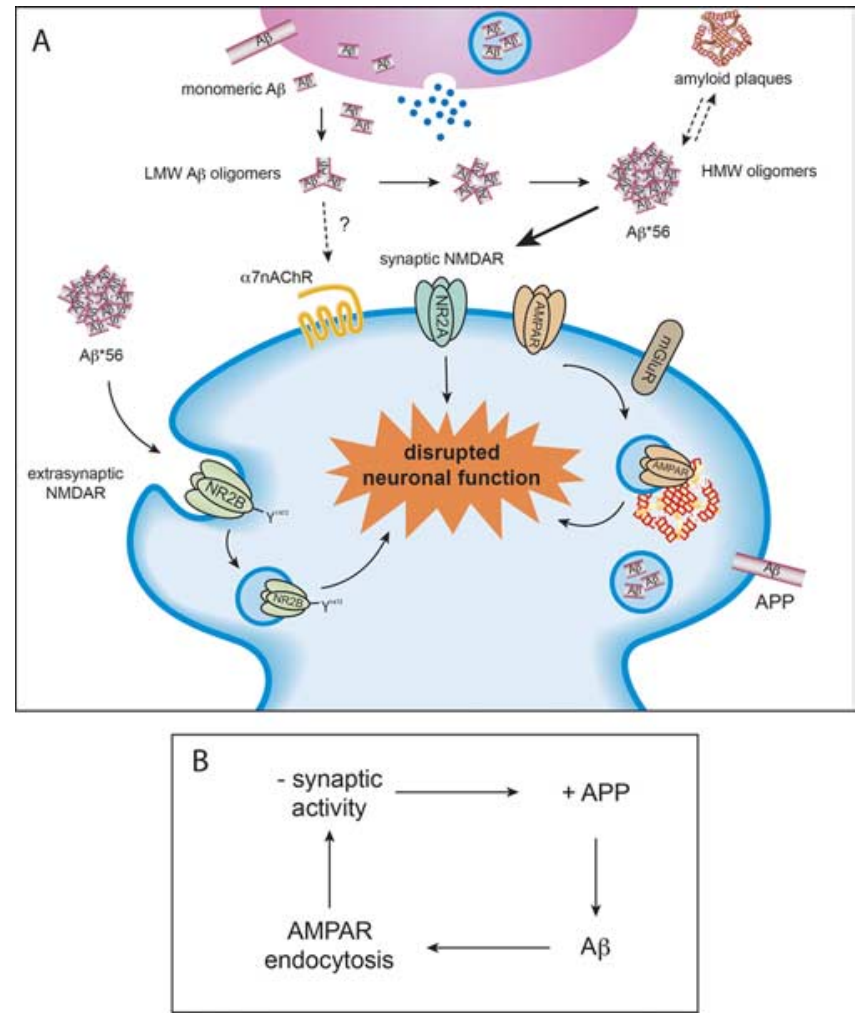

Figure 2. $A$, Potential mechanism of action of $A \beta^{*} 56$ at neuronal surface. Monomeric forms of $A \beta$ assemble into progressively larger oligomers, and these are detected in both intracellular endosomes and the extracellular space. One of the larger oligomers $\left(A \beta^{*} 56\right)$ has been shown to disrupt learning in healthy rats. It is thought to disrupt synaptic NMDA and AMPA receptor trafficking. $\boldsymbol{B}$, Recent work suggests that $A \beta$ may act as part of a negative feedback signaling pathway. Enhanced synaptic activity leads to increased APP processing to $A \beta$, which leads to synaptic AMPA receptor endocytosis and reduced synaptic activity. LMW, Low molecular weight; HMW, high molecular weight; $\alpha 7 n A C h R, ~ \alpha 7$-nicotinic acetylcholine receptor; AMPAR, AMPA receptor; NMDAR, NMDA receptor; mGluR, metabotropic glutamate receptor.

sented showing correlations between $\mathrm{A} \beta \beta^{\star} 56$ and spatial memory impairment at an age when there are no amyloid plaques, neuronal loss, or synaptic loss. The disruptive effects of $A \beta^{\star} 56$ on cognitive function in healthy rats were also shown.

Because glutamate receptors are critical elements in synaptic plasticity and memory, studies are underway to explore the possibility that $\mathrm{A} \beta \beta^{\star} 56$ impairs memory by interacting directly with glutamate receptors. Preliminary data suggest that $\mathrm{A} \beta^{\star} 56$ coimmunoprecipitates with NR1 and NR2A subunits but not with AMPA receptor GluR1, GluR2 subunits, or the $\alpha 7$-nicotinic acetylcholine receptor. These results raise the possibility that $\mathrm{A} \beta^{\star} 56$ could physically interact with NMDA receptors at plasma membranes to alter neuronal function well before neuronal death occurs and might interfere with memory function in the preclinical phases of AD.

The levels of $\mathrm{A} \beta$-derived diffusible ligands (ADDLs) are significantly higher in the spinal fluid and brain tissue of Alzheimer's disease patients compared with control subjects (Gong et al., 2003; Georganopoulou et al., 2005). Studies of ADDLs in the prodromal phase of AD, also known as mild cognitive impairment (MCI), have not been reported. In Tg2576 mice, ADDLs increase throughout life, in contrast to $\mathrm{A} \beta^{\star} 56$, whose levels remain stable. Therefore, $\mathrm{A} \beta^{\star} 56$ and $\mathrm{AD}$ DLs may represent different $A \beta$ species. Experiments have begun to test the hypothesis that $A \beta^{\star} 56$ levels increase before the diagnosis of $\mathrm{AD}$ by measuring $\mathrm{A} \beta{ }^{\star} 56$ levels in brain tissue 
from the Religious Orders Study of individuals with MCI, as well as noncognitively impaired subjects and persons with probable AD. Initial results are encouraging, showing comparable elevations of $A \beta^{\star} 56$ in MCI and probable AD compared with lower levels in unimpaired subjects.

\section{$\beta$ amyloid and neuronal activity}

Roberto Malinow reviewed studies that have focused on two questions: (1) does neuronal activity modulate the formation of $\mathrm{A} \beta$, and (2) does $\mathrm{A} \beta$ in turn modulate neuronal activity? His laboratory has shown that neuronal activity increases the formation of $\mathrm{A} \beta$ and that increased $\mathrm{A} \beta$ leads to depression of excitatory synaptic transmission (Kamenetz et al., 2003) (Fig. 2B). These two findings have led to the hypothesis that $A \beta$ may normally serve as a negative feedback signal that maintains neuronal activity within a normal dynamic range: too much neuronal activity leads to formation of more $\mathrm{A} \beta$, which depresses excitatory synapses and reduces neuronal activity. Recent in vivo studies on wild-type animals (Cirrito et al., 2005) and in vitro studies on wild-type (Ting et al., 2007) and knock-out (Priller et al., 2006) animals support this view.

More recently, the laboratory examined the mechanisms by which A $\beta$ depresses excitatory synapses (Hsieh et al., 2006). Several parallels exist between long-term depression (LTD) and $\mathrm{A} \beta$-induced synaptic changes. $\mathrm{A} \beta$ overexpression decreases spine density, partially occludes metabotropic glutamate receptor-dependent LTD, decreases synaptic AMPA receptor number, and requires second-messenger pathways implicated in LTD for its depressive effects. Expression of an AMPA receptor mutant that prevents its LTD-driven endocytosis blocks the morphological and synaptic depression induced by $\mathrm{A} \beta$. Furthermore, $\mathrm{A} \beta$ can drive phosphorylation of AMPA receptor at a site important for AMPA receptor endocytosis during LTD, and mimicking this AMPA receptor phosphorylation produces the morphological and synaptic depression induced by $\mathrm{A} \beta$. Together, the results show that $\mathrm{A} \beta$ generates structural and synaptic abnormalities via endocytosis of AMPA receptors. Additional questions to be examined include whether the release of presynaptic or postsynaptic $A \beta$ is responsible for the observed synaptic depression, whether there is a difference between acute and chronic exposure to elevated $\mathrm{A} \beta$ levels, and whether different $\mathrm{A} \beta$ oligomeric forms lead to different synaptic effects.

\section{References}

Almeida CG, Tampellini D, Takahashi RH, Greengard P, Lin MT, Snyder EM, Gouras GK (2005) Beta-amyloid accumulation in APP mutant neurons reduces PSD-95 and GluR1 in synapses. Neurobiol Dis 20:187-198.

Antonarakis SE, Lyle R, Dermitzakis ET, Reymond A, Deutsch S (2004) Chromosome 21 and down syndrome: from genomics to pathophysiology. Nat Rev Genet 10:725-738.

Beyreuther K, Pollwein P, Multhaup G, Mönning U, König G, Dyrks T, Schubert W, Masters CL (1993) Regulation and expression of the Alzheimers beta/A4 amyloid protein precursor in health, disease and Down's syndrome. Ann NY Acad Sci 695:91-102.

Billings LM, Oddo S, Green KN, McGaugh JL, LaFerla FM (2005) Intraneuronal Abeta causes the onset of early Alzheimer's disease-related cognitive deficits in transgenic mice. Neuron 45:675-688.

Braithwaite SP, Paul S, Nairn AC, Lombroso PJ (2006) Synaptic plasticity: one STEP at a time. Trends Neurosci 29:452-458.

Chin J, Palop JJ, Yu G-Q, Kojima N, Masliah E, Mucke L (2004) Fyn kinase modulates synaptotoxicity, but not aberrant sprouting, in human amyloid precursor protein transgenic mice. J Neurosci 24:4692-4697.

Chin J, Palop JJ, Puoliväli J, Massaro C, Bien-Ly N, Gerstein H, Scearce-Levie K, Masliah E, Mucke L (2005) Fyn kinase induces synaptic and cognitive impairments in a transgenic mouse model of Alzheimer's disease. J Neurosci 25:9694-9703.

Cirrito JR, Yamada KA, Finn MB, Sloviter RS, Bales KR, May PC, Schoepp DD, Paul SM, Mennerick S, Holtzman DM (2005) Synaptic activity regulates interstitial fluid amyloid-beta levels in vivo. Neuron 48:913-922.

Cleary JP, Walsh DM, Hofmeister JJ, Shankar GM, Kuskowski MA, Selkoe DJ, Ashe K (2005) Natural oligomers of the amyloid-beta protein specifically disrupt cognitive function. Nat Neurosci 8:79-84.

Cui J, Matkovich SJ, deSouza N, Li S, Rosemblit N, Marks AR (2004) Regulation of the type 1 inositol 1,4,5-trisphosphate receptor by phosphorylation at tyrosine 353. J Biol Chem 279:16311-16316.

Davisson MT, Schmidt C, Reeves RH, Irving NG, Akeson EC, Harris BS, Bronson RT (1993) Segmental trisomy as a mouse model for Down syndrome. Prog Clin Biol Res 384:117-133.

Deutsch SI, Rosse RB, Mastropaolo J, Chilton M (2003) Progressive worsening of adaptive functions in Down syndrome may be mediated by the complexing of soluble Abeta peptides with the alpha 7 nicotinic acetylcholine receptor: therapeutic implications. Clin Neuropharmacol 26:277-283.

Echeverria V, Ducatenzeiler A, Alhonen L, Janne J, Grant SM, Wandosell F, Muro A, Baralle F, Li H, Duff K, Szyf M, Cuello AC (2004) Rat transgenic models with a phenotype of intracellular Abeta accumulation in hippocampus and cortex. J Alzheimers Dis 6:209-219.

Epstein CJ (1990) The consequences of chromosome imbalance. Am J Med Genet Suppl 7:31-37.

Escorihuela RM, Fernández-Teruel A, Vallina IF, Baamonde C, Lumbreras MA, Dierssen M, Tobeña A, Florez J (1995) A behavioral assessment of Ts65Dn mice: a putative Down syndrome model. Neurosci Lett 199:143-146.

Georganopoulou DG, Chang L, Nam JM, Thaxton CS, Mufson EJ, Klein WL, Mirkin CA (2005) Nanoparticle-based detection in cerebral spinal fluid of a soluble pathogenic biomarker for Alzheimer's disease. Proc Natl Acad Sci USA 102:2273-2276.

Glabe C (2001) Intracellular mechanisms of amyloid accumulation and pathogenesis in Alzheimer's disease. J Mol Neurosci 17:137-145.

Glenner GG, Wong CW (1984) Alzheimer's disease and Down's syndrome: sharing of a unique cerebrovascular amyloid fibril protein. Biochem Biophys Res Commun 122:1131-1135.

Goate A, Chartier-Harlin M-C, Mullan M, Brown J, Crawford F, Fidani L, Giuffra L, Haynes A, Irving N, James L, Mant R, Newton P, Rooke K, Roques P, Talbot C, Pericak-Vance M, Roses A, Williamson R, Rossor M, Owen M, Hardy J (1991) Segregation of a missense mutation in the amyloid precursor protein gene with familial Alzheimer's disease. Nature 349:704-706.

Goldgaber D, Lerman MI, McBride OW, Saffiotti U, Gajdusek DC (1987) Characterization and chromosomal localization of a cDNA encoding brain amyloid of Alzheimer's disease. Science 235:877-880.

Gong Y, Chang L, Viola KL, Lacor PN, Lambert MP, Finch CE, Krafft GA, Klein WL (2003) Alzheimer's disease-affected brain: presence of oligomeric A beta ligands (ADDLs) suggests a molecular basis for reversible memory loss. Proc Natl Acad Sci USA 100:10417-10422.

Gouras GK, Almeida CG, Takahashi RH (2005) Intraneuronal Abeta accumulation and origin of plaques in Alzheimer's disease. Neurobiol Aging 26:1235-1244.

Griffin WS, Sheng JG, McKenzie JE, Royston MC, Gentleman SM, Brumback RA, Cork LC, Del Bigio MR, Roberts GW, Mrak RE (1998) Life-long overexpression of S100beta in Down's syndrome: implications for Alzheimer pathogenesis. Neurobiol Aging 19:401-405.

Hallett PJ, Spoelgen R, Standaert DG, Dunah AW (2006) Dopamine D activation potentiates striatal NMDA receptors by tyrosine phosphorylationdependent subunit trafficking. J Neurosci 26:4690-4700.

Hardy JA, Higgins GA (1992) Alzheimer's disease: the amyloid cascade hypothesis. Science 256:184-185.

Hardy JA, Selkoe DJ (2002) The amyloid hypothesis of Alzheimer's disease: progress and problems on the road to therapeutics. Science 297:353-356.

Holtzman DM, Li YW, Gage FH, DeArmond SJ, Epstein CJ, McKinley MP, Mobley WC (1991) Modeling cholinergic abnormalities in Down syndrome and Alzheimer's disease. Prog Clin Biol Res 373:189-202.

Holtzman DM, Santucci D, Kilbridge J, Chua-Couzens J, Fontana DJ, Daniels SE, Johnson RM, Chen K, Sun Y, Carlson E, Alleva E, Epstein CJ, Mobley WC (1996) Developmental abnormalities and age-related neurodegen- 
eration in a mouse model of Down syndrome. Proc Natl Acad Sci USA 93:13333-13338.

Hsia AY, Masliah E, McConlogue L, Yu GQ, Tatsuno G, Hu K, Kholodenko D, Malenka RC, Nicoll RA, Mucke L (1999) Plaque-independent disruption of neural circuits in Alzheimer's disease mouse models. Proc Natl Acad Sci USA 96:3228-3233.

Hsieh H, Boehm J, Sato C, Iwatsubo T, Tomita T, Sisodia S, Malinow R (2006) AMPAR removal underlies Abeta-induced synaptic depression and dendritic spine loss. Neuron 52:831-843.

Hunter CL, Bimonte HA, Granholm AC (2003) Behavioral comparison of 4 and 6 month-old Ts65Dn mice: age-related impairments in working and reference memory. Behav Brain Res 138:121-131.

Kamenetz F, Tomita T, Hsieh H, Seabrook G, Borchelt D, Iwatsubo T, Sisodia S, Malinow R (2003) APP processing and synaptic function. Neuron 37:925-937.

Kang J, Lemaire HG, Unterbeck A, Salbaum JM, Masters CL, Grzeschik KH, Multhaup G, Beyreuther K, Müller-Hill B (1987) The precursor of Alzheimer's disease amyloid A4 protein resembles a cell-surface receptor. Nature 325:733-736.

Katzman R, Terry R, DeTeresa R, Brown T, Davies P, Fuld P, Renbing X, Peck A (1988) Clinical, pathological, and neurochemical changes in dementia: a subgroup with preserved mental status and numerous neocortical plaques. Ann Neurol 23:138-144.

Kayed R, Head E, Thompson JL, McIntire TM, Milton SC, Cotman CW, Glabe CG (2003) Common structure of soluble amyloid oligomers implies common mechanism of pathogenesis. Science 300:486-489.

Klein WL (2002) Abeta toxicity in Alzheimer's disease: globular oligomers (ADDLs) as new vaccine and drug targets. Neurochem Int 41:345-352.

Klein WL, Krafft GA, Finch CE (2001) Targeting small Abeta oligomers: the solution to an Alzheimer's disease conundrum? Trends Neurosci 24:219-224.

Kleschevnikov AM, Belichenko PV, Villar AJ, Epstein CJ, Malenka RC, Mobley WC (2004) Hippocampal long-term potentiation suppressed by increased inhibition in the Ts65Dn mouse, a genetic model of Down syndrome. J Neurosci 24:8153-8160.

Knobloch M, Konietzko U, Krebs DC, Nitsch RM (2007) Intracellular Abeta and cognitive deficits precede beta-amyloid deposition in transgenic arcAbeta mice. Neurobiol Aging 28:1297-1306.

Kojima N, Ishibashi H, Obata K, Kandel ER (1998) Higher seizure susceptibility and enhanced tyrosine phosphorylation on $N$-methyl-D-aspartate receptor subunit 2B in fyn transgenic mice. Learn Mem 5:429-445.

Lacor PN, Buniel MC, Chang L, Fernandez SJ, Gong Y, Viola KL, Lambert MP, Velasco PT, Bigio EH, Finch CE, Krafft GA, Klein WL (2004) Synaptic targeting by Alzheimer's-related amyloid beta oligomers. J Neurosci 24:10191-10200.

Lacor PN, Buniel MC, Furlow PW, Clemente AS, Velasco PT, Wood M, Viola KL, Klein WL (2007) Abeta oligomer-induced aberrations in synapse composition, shape, and density provide a molecular basis for loss of connectivity in Alzheimer's disease. J Neurosci 27:796-807.

LaFerla FM, Green KN, Oddo S (2007) Intracellular amyloid-beta in Alzheimer's disease. Nat Rev Neurosci 8:499-509.

Lambert MP, Barlow AK, Chromy BA, Edwards C, Freed R, Liosatos M, Morgan TE, Rozovsky I, Trommer B, Viola KL, Wals P, Zhang C, Finch CE, Krafft GA, Klein WL (1998) Diffusible, nonfibrillar ligands derived from $A \beta_{1-42}$ are potent central nervous system neurotoxins. Proc Natl Acad Sci USA 95:6448-6453.

Larson J, Lynch G, Games D, Seubert P (1999) Alterations in synaptic transmission and long-term potentiation in hippocampal slices from young and aged PDAPP mice. Brain Res 840:23-35.

Lesne S, Koh MT, Kotilinek L, Kayed R, Glabe CG, Yang A, Gallagher M, Ashe $\mathrm{KH}$ (2006) A specific amyloid- $\beta$ protein assembly in the brain impairs memory. Nature 440:352-357.

Levy-Lahad E, Wasco W, Poorkaj P, Romano DM, Oshima J, Pettingell WH, Yu C, Jondro PD, Schmidt SD, Wang K, Crowley AC, Fu Y, Guenette SY, Galas D, Nemens E, Wijsman EM, Bird TD, Schellenberg GD, Tanzi RE (1995) Candidate gene for the chromosome 1 familial Alzheimer's disease locus. Science 269:973-977.

Lombroso PJ, Murdoch G, Lerner M (1991) Molecular characterization of a protein tyrosine phosphatase enriched in striatum. Proc Natl Acad Sci USA 88:7242-7246.

Lombroso PJ, Naegele JR, Sharma E, Lerner M (1993) A protein tyrosine phosphatase expressed within dopaminoceptive neurons of the basal ganglia and related structures. J Neurosci 13:3064-3074.

Lott IT, Head E, Doran E, Busciglio J (2006) Beta-amyloid, oxidative stress and down syndrome. Curr Alzheimer Res 3:521-528.

Lu YF, Kojima N, Tomizawa K, Moriwaki A, Matsushita M, Obata K, Matsui H (1999) Enhanced synaptic transmission and reduced threshold for LTP induction in fyn-transgenic mice. Eur J Neurosci 11:75-82.

Mahley RW, Weisgraber KH, Huang Y (2006) Apolipoprotein E4: A causative factor and therapeutic target in neuropathology, including Alzheimer's disease. Proc Natl Acad Sci USA 103:5644-5651.

Mullan M, Crawford F, Axelman K, Houlden H, Lilius L, Winblad B, Lannfelt L (1992) A pathogenic mutation for probable Alzheimer's disease in the APP gene at the N-terminus of beta-amyloid. Nat Genet 1:345-347.

Nguyen TH, Liu J, Lombroso PJ (2002) Striatal enriched phosphatase 61 dephosphorylates Fyn at phosphotyrosine 420. J Biol Chem 277:24274-24279.

Oddo S, Caccamo A, Shepherd JD, Murphy MP, Golde TE, Kayed R, Metherate R, Mattson MP, Akbari Y, LaFerla FM (2003) Triple-transgenic model of Alzheimer's disease with plaques and tangles: intracellular Abeta and synaptic dysfunction. Neuron 39:409-421.

Oddo S, Caccamo A, Smith IF, Green KN, LaFerla FM (2006) A dynamic relationship between intracellular and extracellular pools of Abeta. Am J Pathol 168:184-194.

Palop JJ, Jones B, Kekonius L, Chin J, Yu G-Q, Raber J, Masliah E, Mucke L (2003) Neuronal depletion of calcium-dependent proteins in the dentate gyrus is tightly linked to Alzheimer's disease-related cognitive deficits. Proc Natl Acad Sci USA 100:9572-9577.

Palop JJ, Chin J, Bien-Ly N, Massaro C, Yeung BZ, Yu G-Q, Mucke L (2005) Vulnerability of dentate granule cells to disruption of Arc expression in human amyloid precursor protein transgenic mice. J Neurosci 25:9686-9693

Palop JJ, Chin J, Roberson ED, Wang J, Thwin MT, Bien-Ly N, Yoo J, Ho KO, Yu G-Q, Kreitzer A, Finkbeiner S, Noebels JL, Mucke L (2007) Aberrant excitatory neuronal activity and compensatory remodeling of inhibitory hippocampal circuits in mouse models of Alzheimer's disease. Neuron 55:697-711.

Paul S, Nairn AC, Wang P, Lombroso PJ (2003) NMDA-mediated activation of the tyrosine phosphatase STEP regulates the duration of ERK signaling 6:34-42.

Priller C, Bauer T, Mitteregger G, Krebs B, Kretzschmar HA, Herms J (2006) Synapse formation and function is modulated by the amyloid precursor protein. J Neurosci 26:7212-7221.

Robakis N, Ramakrishna N, Wolfe G, Wisniewski H (1987) Molecular cloning and characterization of a CDNA encoding the cerebrovascular and the neuritic plaque amyloid peptides. Proc Natl Acad Sci USA 84:4190-4194.

Rogaev EI, Sherrington R, Rogaeva EA, Levesque G, Ikeda M, Liang Y, Chi H, Lin C, Holman K, Tsuda K, Mar L, Sorbi S, Nacmias B, Piacentini S, Amaducci L, Chumakov I, Cohen D, Lannfelt L, Fraser PE, Rommens JM, St George-Hyslop PH (1995) Familial Alzheimer's disease in kindreds with missense mutations in a gene on chromosome 1 related to the Alzheimer's disease type 3 gene. Nature 376:775-778.

Salter MW, Kalia LV (2004) Src kinases: a hub for NMDA receptor regulation. Nat Rev Neurosci 5:317-328.

Schupf N, Sergievsky GH (2002) Genetic and host factors for dementia in Down's syndrome. Br J Psychiatry 180:405-410.

Selkoe DJ (1991) The molecular pathology of Alzheimer's disease. Neuron 6:487-498.

Shankar GM, Bloodgood BL, Townsend M, Walsh DM, Selkoe DJ, Sabatini BL (2007) Natural oligomers of the Alzheimer amyloid-beta protein induce reversible synapse loss by modulating an NMDA-type glutamate receptor-dependent signaling pathway. J Neurosci 27:2866-2875.

Sherrington R, Rogaev E, Liang Y, Rogaeva Y, Levesque G, Ikeda M, Chi H, Lin C, Li G, Holman K, Tsuda T, Mar L, Foncin JF, Bruni AC, Montesi MP, Sorbi S, Rainero I, Pinessi L, Nee L, Chumakov I, et al. (1995) Cloning of a gene bearing missense mutations in early-onset familial Alzheimer's disease. Nature 375:754-760.

Siarey RJ, Stoll J, Rapoport SI, Galdzicki Z (1997) Altered long-term potentiation in the young and old Ts65Dn mouse, a model for Down syndrome. Neuropharmacology 36:1549-1554.

Snyder EM, Nong Y, Almeida CG, Paul S, Moran T, Choi EY, Nairn AC, Salter MW, Lombroso PJ, Gouras GK, Greengard P (2005) Regulation of NMDA receptor trafficking by amyloid-beta. Nat Neurosci 8:1051-1058. 
Strittmatter W, Saunders A, Schmechel D, Pericak-Vance M, Enghild J, Salvesen G, Roses A (1993) Apolipoprotein E: high-avidity binding to beta-amyloid and increased frequency of type 4 allele in late-onset familial Alzheimer disease. Proc Natl Acad Sci USA 90:1977-1981.

Takahashi RH, Almeida CG, Kearney PF, Yu F, Lin MT, Milner TA, Gouras GK (2004) Oligomerization of Alzheimer's $\beta$-amyloid within processes and synapses of cultured neurons and brain. J Neurosci 24:3592-3599.

Tampellini D, Magrané J, Takahashi RH, Li F, Lin MT, Almeida CG, Gouras GK (2007) Internalized antibodies to the Abeta domain of APP reduce neuronal Abeta and protect against synaptic alterations. J Biol Chem 282:18895-18906.

Tanzi RE, Bertram L (2005) Twenty years of the Alzheimer's disease amyloid hypothesis: a genetic perspective. Cell 120:545-555.

Tanzi R, Gusella JF, Watkins PC, Bruns GA, St George-Hyslop P, Van Keuren ML, Patterson D, Pagan S, Kurnit DM, Neve RL (1987) Amyloid beta protein gene: cDNA, mRNA distribution, and genetic linkage near the Alzheimer locus. Science 235:880-884.

Terry RD, Masliah E, Salmon DP, Butters N, DeTeresa R, Hill R, Hansen LA, Katzman R (1991) Physical basis of cognitive alterations in Alzheimer's disease: synapse loss is the major correlate of cognitive impairment. Ann Neurol 30:572-580.

Ting JT, Kelley BG, Lambert TJ, Cook DG, Sullivan JM (2007) Amyloid precursor protein overexpression depresses excitatory transmission through both presynaptic and postsynaptic mechanisms. Proc Natl Acad Sci USA 104:353-358.

Vezzani A, Sperk G, Colmers WF (1999) Neuropeptide Y: Emerging evidence for a functional role in seizure modulation. Trends Neurosci 22:25-30.

Walsh DM, Selkoe DJ (2004) Deciphering the molecular basis of memory failure in Alzheimer's disease. Neuron 44:181-193.

Walsh DM, Klyubin I, Fadeeva JV, Cullen WK, Anwyl R, Wolfe MS, Rowan MJ, Selkoe DJ (2002) Naturally secreted oligomers of amyloid beta protein potently inhibit hippocampal long-term potentiation in vivo. Nature 416:535-539.

Wolvetang EW, Bradfield OM, Tymms M, Zavarsek S, Hatzistavrou T, Kola I, Hertzog PJ (2003) The chromosome 21 transcription factor ETS2 transactivates the beta-APP promoter: implications for Down syndrome. Biochim Biophys Acta 1628:105-110. 